\title{
O LUDIČKOJ KLETVI U HUMORNOM DISKURSU INTERNETSKIH ŽANROVA
}

Izvorni znanstveni rad Primljeno: 4. 4. 2021. Prihvaćeno: 7. 9. 2021. DOI: 10.15176/vol58no208 UDK 398.2 004.738 $82.0: 39$

\section{ŽELJKO PREDOJEVIĆ}

Katedra slavenskih filologija, Filozofski fakultet, Sveučilište Komenski u Bratislavi

\begin{abstract}
Rad je usmjeren na prikaz ironiziranja žanra kletve u humornom diskursu internetskih žanrova. Kletva je u kolektivnom pamćenju verbalni magijski žanr što podrazumijeva izricanje zla nekome, a u humornom diskursu internetskih žanrova primjenjuje se na neočekivano iskustvo čime se stvara ironijski nesklad između onoga što žanr kletve pretpostavlja i njegove uloge u digitalnom folkloru. Osim ironiziranja žanra kletve, zamjećuje se i kletvi atipična uloga stvaranja humorna učinka u diskursu internetskih žanrova. Ovakve šaljive inačice žanra kletve u digitalnom folkloru označene su terminom ludička kletva. Ludičke kletve su izrečene u šali, ali u sebi čuvaju ostatke vjerovanja u magijsku moć riječi što je razvidno korištenjem kletvi imanentnih formulacija, a prije svega konektora dabogda. Njime se evocira izricatelju kletve imanentna želja nekome nanijeti zlo, no primjenjuje se u duhovitu kontekstu čime se osjećajem neskladnosti ili nepodudarnosti stvara humorni učinak. Istraživanje je usmjereno na korisničke profile mrežne stranice Mudrolije sa Twittera na društvenim mrežama Facebook i Instagram.
\end{abstract}

Ključne riječi: kletva, ludička kletva, humor, digitalni folklor, društvene mreže, internetski žanrovi, tvit, podijeljene priče

$\operatorname{Rad}^{1}$ je usmjeren na prikaz ironiziranja usmenoretoričkoga žanra kletve ${ }^{2}$ i njegove atipične uloge u humornom diskursu internetskih žanrova u kontekstu digitalnog folklora (engl. weblore, Internet lore, netlore). Prvo će se govoriti o internetskim žanrovima u kojima se pojavljuje žanr kletve, zatim ukazati na njihovu povezanost s "klasičnim" folklornim žanrovima, a na koncu i izvedbeno i sadržajno opisati tzv. ludičku kletvu u humornom diskursu internetskih žanrova. Izvorna ritualna uloga kletve koja počiva na vjerovanju

1 Štúdia vznikla v rámci riešenia grantového projektu Ministerstva školstva, vedy, výskumu a športu Slovenskej republiky VEGA 1/0666/21 Percepcia nadprirodzena v jazykoch a kultúrach Slovanov s akcentom na západoslovanský a južnoslovanský areál II. (Rad je nastao u okviru znanstveno-istraživačkoga projekta Percepcija nadnaravnoga u jezicima i kulturama Slavena s naglaskom na zapadnoslavenski i južnoslavenski areal II.).

2 U radu se neće govoriti o problematici klasifikacije kletve kao žanra u povijesti i teoriji folkloristike. Za više o tome vidi Kitz 2104: 9-32; Nikolić 2015, 2017, 2019 i Nikolić i Tomašić 2018. 
u magijsku moć riječi (usp. Solar 2007: 187; Nikolić 2010; Popović 2010: 345; Botica 2013: 486; Vukelić 2014: 257; Kitz 2014: 68-69; Endstrasser 2020: 235) s vremenom postaje deritualizirana (engl. deritualised) te se jezični elementi nekada magijskih formulacija javljaju u svakodnevnoj komunikaciji i bez adresantove želje za izricanjem zla (usp. Nikolić 2010: 148; Kádár i Szalai 2019: 3) ili kao poštapalice u određenim tipovima govora (usp. Solar 2007: 187). Proces njezine rudimentacije, tj. svođenje na formulni izraz ili poštapalicu, primjećuje se već u starijoj književnosti (usp. Nikolić 2010: 148), a danas se u svakodnevnoj komunikaciji na jezicima štokavskoga dijalekta prepoznaje uglavnom po konektoru dabogada i izraženoj afektivnosti govornika. Upravo se zbog izražene afektivnosti povezuje i s psovkama i uvredama (usp. Jay 1992: 2; Solar 2007: 187; Badurina i Pranjković 2019), no Davor Nikolić napominje da "kletva u pravilu inzistira na posredovanju nadnaravnog autoriteta i najčešće je lišena opscenih izraza" (2017: 365). Psovka je izravno vrijeđanje, a kletva želja da nekoga snađe zlo, no povezuje ih negativno emocionalno, afektivno izražavanje (usp. Tomelić Ćurlin i Runjić-Stoilova 2010: 378).

U engleskoj literaturi prepoznata su dva oblika kletvi - ozbiljne (engl. serious) i ludičke (engl. ludic), pri čemu se razlika među njima zasniva na vjerovanju u magijsku moć riječi, tj. ludičke su one izrečene u šali, ljutnji ili bijesu i u njima ne dolazi do adresantove želje za izricanjem zla (usp. Danet i Bogoch 1992: 134-135; Culpeper i Semino 2000: 103; Archer 2010: 398). lako je "klasična", tzv. ozbiljna kletva i dalje prisutna u suvremenim usmenoknjiževnim zapisima (usp. Botica 2005: 153), korak dalje u njezinoj deritualiziranosti zamjećuje se u računalno posredovanoj komunikaciji na društvenim mrežama, gdje se njezina ritualna uloga kojom se nekome želi zlo ironizira i primjenjuje na neočekivano iskustvo u kojem se humoristično aktualizira ("Dabogda ti trebala k'o punjač za android") ili se adresatu umjesto zla želi nešto dobro ("Dabogda nas sve u životu žuljali samo kamenčići na obali mora!"). ${ }^{3}$ Ovakav ludički način aktualiziranja kletve nije svojstven samo digitalnom folkloru, dapače, kletva se u usmenim i pisanim književnim izričajima koristi kao sredstvo izraza grube, najčešće opscene komike (Solar 2007: 187), njezina forma se često upotrebljava za izricanje blagoslova (usp. Živković 1985: 336; Botica 2013: 475) ili se javlja ironijski kletveni diskurs kao postupak stilizacije književnoga teksta (usp. Lemac 2011). No što se tiče digitalnoga folklora, zanimljivo je da je ludički oblik kletve uvelike zastupljeniji negoli ozbiljna kletva ili oblik kletve kojim se nekoga želi uvrijediti.

\section{INTERNETSKI (HUMORNI) ŽANROVI I NJIHOV SUODNOS S KLASIČNIMA}

Jedno od osnovnih obilježja suvremene internetske komunikacije prakticiranje je i širenje humora (usp. Shifman 2007: 187; Laineste i Voolaid 2016: 27; Yus 2021a: 1), a od pojave

${ }^{3}$ Analizirani primjeri prenose se u izvornom obliku, tj. bez gramatičkih ili pravopisnih korekcija i svi se nalaze na korisničkim profilima mrežne stranice Mudrolije sa Twittera na društvenim mrežama Facebook i Instagram. 
društvenih mreža internetski korisnici prestaju biti pasivni uživatelji humora čitajući ili gledajući šale na internetskim stranicama, već sudjeluju u njihovu stvaranju (usp. Weitz 2016: 2). Shodno tomu razvijaju se vizualni, verbalni i vizualno-verbalni (humorni) internetski žanrovi prilagođeni internetskoj ili računalno posredovanoj komunikaciji (usp. npr. Giltrow i Stein 2009; Heyd 2009; McNeill 2013; Shifman 2014; Page 2018). Ovaj je rad usmjeren na humorni diskurs tvitova (engl. tweet), tj. statusa ${ }^{4}$ s društvene mreže Twitter što ih je uredništvo mrežne stranice Mudrolije sa Twittera uredilo kao verbalne (tekstualne) artefakte digitalne kulture napisane na istom predlošku i objavilo na svojim korisničkim profilima ${ }^{5}$ na društvenim mrežama Facebook i Instagram. Nadalje, interakcijom korisnika na njih nastaje novi internetski multimedijalni posredovani narativni žanr podijeljenih priča (engl. shared stories) definiran "kao prepričavanje, koje su proizveli mnogi kazivači, kroz iterativne tekstualne segmente, a koje promovira zajedničke stavove svojih kazivača" (Page 2018: 18). lako se na prvi pogled čini da je riječ o kompliciranom spoju više internetskih žanrova, to je upravo i njihova osnovna karakteristika - uređivanje, komentiranje, dodavanje novih detalja, zajedničko pripovijedanje i dijeljenje unutar internetske zajednice (usp. Laineste i Voolaid 2016: 32; Shifman 2014: 32; Page 2018: 18-23) koju uglavnom čini jedna mrežna stranica ili profil na društvenim mrežama.

Humorni diskurs internetskih žanrova strukturalno ima mnogo poveznica s "klasičnim" folklornim žanrovima. Internetski (humorni) žanrovi često uspostavljaju određeni suodnos s klasičnima, tj. u njima se prepoznaju njihove strukture i sadržaji (usp. npr. Baran 2012; Dynel 2016; Laineste i Voolaid 2016; Predojević, 2021b) ili se "ponašaju" na njima analogan način u usmenom komuniciranju (usp. Oring 2016: 129-146; Predojević 2019, 2021a). Primjeri analizirani u ovom radu nastali su od tvitova, statusa s društvene mreže Twitter, a u posljednje se vrijeme ukazuje i na narativnost statusa s društvenih mreža (usp. Page 2010; Dayter 2016: 175-198; Sadler 2018; Page 2018: 1-25) te se napominje da se tvitovi mogu analizirati bilo kojom poznatom tekstnom analizom, pa tako i žanrovski (usp. Sæbø 2011: 4-5). Prema Weitzovu mišljenju (2016: 1-2), načela produkcije humora u računalno posredovanoj komunikaciji na društvenim mrežama ostaju ista, ali tehnologije koje koristimo oblikuju načine na koje se šalimo. Liisi Laineste (2016: 21) napominje da je ponekad samo upotreba poznatih žanrova u novom kontekstu već dovoljna za stvaranje humora. Važno je napomenuti da se internetski žanrovi, zbog konteksta njihova nastanka i načina dijeljenja među recipijentima tj. korisnicima, ne trebaju izjednačavati s klasičnima, ali se tekstovi koji se u/na njima pojavljuju mogu promatrati kao oni koji su nastali po uzoru na strukturu i sadržaj klasičnih folklornih žanrova. Dakle, internetske žanrove treba razlikovati od klasičnih - internetski žanrovi su izvorni mrežni oblik u kojem se pojavljuju analizirani primjeri, a humorni diskurs koji se u/na njima nalazi može se promatrati u suodnosu s klasičnim folklornim žanrovima, tj. mogu se promatrati kao njihovi virtualni surogati.

\footnotetext{
${ }^{4}$ Riječ status se u računalnom nazivlju odnosi na uglavnom kratak tekst koji korisnici dijele $s$ drugim korisnicima na društvenim mrežama, a posebice na Facebooku i Twitteru, s tim da se status na mreži Twitter naziva i tvit (engl. tweet).

${ }^{5}$ Riječ profil u ovom radu odnosi se na korisnički profil na društvenim mrežama.
} 


\section{ANALIZA LUDIČKE KLETVE U HUMORNOM DISKURSU INTERNETSKIH ŽANROVA I NJEZIN SUODNOS S OZBILJNOM NA PRIMJERU KORISNIČKOGA PROFILA MUDROLIJE SA TWITTERA}

Istraživanje je usmjereno na internetske žanrove objavljene na korisničkim profilima mrežne stranice Mudrolije sa Twittera $^{6}$ na društvenim mrežama Instagram7 i Facebook. ${ }^{8}$ Administratori profila prate tvitove korisnika iz zemalja južnoslavenskog areala na svim jezicima štokavskoga dijalekta ${ }^{9}$ i one najkreativnije urede na prepoznatljivoj im podlozi te objave na svojim korisničkim profilima na društvenim mrežama. Pri tome se verbalna poruka tvita pravopisno i gramatički ne korigira, a objavljeni primjeri mogu se smatrati digitalnim folklornim izričajima (usp. Predojević 2019). Profil je na društvenoj mreži Instagram aktivan od 2013. godine, a na dan 4. travnja 2021. godine, u vrijeme pisanja ovoga rada, imao je nešto više od 13800 objava i preko 864 tisuće pratitelja. ${ }^{10}$ Korpus na kojem se provodi istraživanje čine 44 primjera $^{11}$ u kojima se pojavljuje kletva, a prema obliku kletve može se podijeliti u dvije skupine, tj. na 1) one u kojima se pojavljuje ozbiljna kletva (3 primjera) i 2) one u kojima se pojavljuje ludička kletva (41 primjer). S obzirom na to da je cilj ovoga rada prvenstveno analizirati ludičku kletvu, te da su zabilježena samo tri primjera ozbiljne kletve, ${ }^{12}$ detaljno će se analizirati samo primjeri u kojima je zabilježena ludička. Humorni diskurs internetskih žanrova prvo će se žanrovski analizirati, a zatim i izvedbeno i sadržajno da bi se uvidjele sličnosti i razlike između ludičke kletve u digitalnom folkloru i kletve u usmenoj tradiciji, s osnovnom hipotezom da je uloga ludičke kletve u diskursu internetskih žanrova stvaranje humorna učinka.

S obzirom na to da se kletva u usmenoj književnosti javlja kao samostalan iskaz ili kao iskaz u okviru drugih žanrova i oblika (usp. Ajdačić; Botica 2013: 486), dva su načina za žanrovsku analizu ludičke kletve u kontekstu digitalnog folklora. Može se promatrati u

\footnotetext{
${ }^{6}$ Mrežna stranica Mudrolije sa Twittera, https://mudrolije.org/ (pristup 4. 4. 2021.).

${ }^{7}$ Korisnički profil Mudrolije sa Twittera, https://www.instagram.com/mudrolijesatwittera/?hl=hr (pristup 4. 4. 2021.). 2021.).

${ }^{8}$ Korisnički profil Mudrolije sa Twittera, https://www.facebook.com/MudrolijeCommunity (pristup 4. 4.

${ }^{9}$ Budući da administratori stranice Mudrolije sa Twittera prate tvitove korisnika iz svih država bivše Jugoslavije, u ovom se je radu teško ograničiti samo na hrvatski jezik. Stoga će kao primjeri u analitičkome dijelu rada poslužiti primjeri na svim zastupljenim jezicima na stranici, tj. na svim jezicima štokavskoga dijalekta.

${ }^{10} \mathrm{Na}$ društvenoj mreži Facebook profil ima više od 620 tisuća pratitelja, a broj objava se ne može utvrditi jer društvena mreža Facebook ne pravi takve statistike.

${ }^{11}$ S obzirom na velik broj objavljenih primjera na profilu Mudrolije sa Twittera, kletva se u njima vjerojatno spominje i češće od u ovom radu zabilježenih primjera. Nadalje, s obzirom na manji broj analiziranih primjera zbog kojih doneseni zaključci mogu biti upitni, bitno je napomenuti da se kletva u humornom diskursu internetskih žanrova pojavljuje i na drugim korisničkim profilima ili mrežnim stranicama od kojih se samo neki i spominju u ovom radu, no korisnički profil Mudrolije sa Twittera odabran je zbog metodologije istraživanja, tj. zbog konzistentnosti istraživanoga korpusa i prostora gdje se on nalazi (usp. Predojević 2019: 157). Dobro je napomenuti i da se kletva na društvenoj mreži Twitter pojavljuje mnogo češće, no ti tvitovi nisu prepoznati kao dovoljno zanimljivi ili smiješni da bi ih administratori Mudrolija sa Twittera uredili.

${ }^{12}$ Zabilježeni primjeri u kojima se pojavljuje ozbiljna kletva: "Dabogda crkli od ciroze i ti i tvoja jetra, jer su se borili srce i mozak", "Dabogda bio zdrav, bogat i nepoznat" i "Volim te al crkni”.
} 
kontekstu internetskih žanrova i u kontekstu humorna diskursa koji internetski žanrovi sadrže, a da ga analiziramo u suodnosu s klasičnim folklornim žanrovima.

\section{ŽANROVSKA ANALIZA U KONTEKSTU FOLKLORNIH ŽANROVA}

Ludička kletva se u humornom diskursu internetskih žanrova pojavljuje na istovjetan način kao i u usmenoj književnosti, tj. kao samostalan iskaz i kao iskaz u okviru drugih folklornih žanrova i oblika.

Kada se pojavljuje kao samostalni iskaz, humorni diskurs imitira žanr kletve u kojem adresanti adresatima izriču zlo na šaljiv način ("Dabogda ti trebala k'o punjač za android"; "Ko voli snijeg dabogda mu u kući pado") ili im pak izriču dobro, tj. javljaju se poruke koje se mogu okarakterizirati kao antikletve ("Dabogda svi menjali popunjeni pasoš jednom godišnje!"; "Dabogda svi na more išli ove godine!"). Takvi oblici koji formom odgovaraju kletvi, a po smislu blagoslovima imanentni su i usmenoj tradiciji (usp. Ajdačić; Botica 2013: 475; Živković 1985: 336). U ovoj se skupini primjera humoristično imitira, tj. ironizira žanr kletve koji prepoznajemo po konektoru dabogada i afektivnosti koja je razvidna po uskličnim rečenicama, ali izostavljena je bitna "žanrovska značajka kletve da samo njezino izgovaranje treba adresatu donijeti nesreću, bolest pa i smrt” (Nikolić 2019: 21). Ovakav oblik aktualizacije žanra kletve često se pojavljuje i na drugim mrežnim portalima na kojima se objavljuju vicevi, šale i drugi duhoviti sadržaji. ${ }^{13}$

U drugoj se skupini primjera kletva pojavljuje kao dio (proto)narativne strukture (usp. Užarević 2008) humorna diskursa što se može različito žanrovski okarakterizirati, a također se prepoznaje po konektoru dabogada i ponekad po izraženoj afektivnosti. Neće se detaljno analizirati uloga ludičke kletve unutar pojedinoga folklornog žanra jer za to je premali broj primjera i takva analiza nadilazi okvire ovoga rada, već je cilj ukazati na njezinu osnovnu ulogu u analiziranom diskursu, a to je stvaranje humorna učinka. Bitno je napomenuti da se i ovakvi primjeri javljaju na drugim profilima na društvenim mrežama. ${ }^{14}$

Primjer koji se može okarakterizirati kao ekspresivni tekst, tj. novogodišnja čestitka ("Dabogda pocrkale bivše ljubavi i sve najjače u 2018. godini hehe"), kletvu humoristično aktualizira ironijskim neskladom (usp. Brozović 2012) uvrštavajući je uz novogodišnje želje.

Zamijećen je usmenoj tradiciji imanentan spoj kletve u zakletvi (“Imam ja te 'nikad-vise' ili 'crkla-majci-ako-opet' odluke. Prosto ne znam koje sam vise puta pogazila. Mrtva trka") kojim se duhovito ukazuje na sumnju u osobne ljudske slabosti koje bi mogle dovesti do zla (usp. Ajdačić).

${ }_{13}$ Primjerice na portalima Show (http://www.show.hr/vic/dabogda/) i Besno pile (https://besnopile.rs/ dabogda-ti-ja-trebao-ko-punjac-za-android-prelistajte-10-vrhunskih-fora/, pristup 7. 2. 2021.).

${ }^{14}$ Vidi primjerice profile Gospodar Pršljenova i Mojne na tonbe na društvenim mrežama. 
U primjerima koji se mogu povezati s aforizmima ("Ljubav je malo 'dođi da se ljubimo na kiši' malo 'dabogda se udavio u blatu”; "od osvajanja sveta kada ustanem do dabogda se ne probudila uvece"), kletva se uvodi na mjesto kakva obrata koji je tipičan za aforistički diskurs (usp. Endstrasser 2020: 233). Zamjećuju se i primjeri u kojima se humorni učinak postiže parafraziranjem aforizama. Primjerice aforizam "Tanka je linija između ljubavi i mržnje” parafraziran je na dva načina uvrštavajući u njega kletvu ("Tanka je linija između dabogda crkla ako ti se javim i javiću se pa nek crknem.”; “tanka je linija između 'volim te' i 'crko dabogda"). Takvi se primjeri mogu okarakterizirati kao antiaforizmi, po uzoru na antiposlovice (usp. Litovkina 2015). Humorni učinak postignut parafraziranjem poslovičnih izraza imanentan je digitalnom folkloru (usp. Predojević 2019).

Zabilježeni su i primjeri što se mogu okarakterizirati kao (reducirani) vicevi u kojima se kletva aktualizira na dva načina. Uvodi se kao poenta u posljednjem dijelu (reducirana) vica ("Bog se javi / A ti nećeš / Ugojila se dabogda") kojom se postiže humorni učinak (usp. Užarević 2012: 74) ili je kletveni diskurs tematsko-motivska okosnica duhovita teksta, a kao scenarijska opreka (usp. Marković 2019: 171) uvodi se kletvi kakvo neočekivano iskustvo.

- Jesam u programu? Može muzička želja?

- Da. Može

- Pozdrav bivšem uz pesmu "Crko da Bog da sve stekao pa sve izgubio ne imao sreće ni ti ni tvoj porod sve te želele a tebi da se ne diže"

- Gospođo nema takva pesma

- Al bila sam u programu?

- Da

- Daj onda nešto od Harisa.

Analizirani humorni diskurs nastao je od osobnih statusa na društvenoj mreži Twitter koja potiče korisnike da podijele s drugim korisnicima što trenutno rade (usp. Zappavigna 2017: 208), stoga korisnici često pišu kratke poruke (statuse, tvitove) o zgodama iz svakodnevnog života, te se veći broj primjera može povezati sa žanrom pričanja o životu (usp. Bošković-Stulli 1988). U njima se kletva uglavnom javlja kao efektan završetak teksta o kakvoj zgodi koja se temelji na vlastitu iskustvu što ga pripovjedač, tj. korisnik društvene mreže Twitter, pripovijeda.

Srela sam bivšeg najvećeg medju svim bivšima. Propao, ugojio se, stomačina do poda, podočnjaci i glavudža ko globus. Navuko neko sranje od odeće. FUJ Ovako bih volela da je izgledao a u stvari nikad lepši nije bio crko dabogada Nemanja

e zbog koga sam ja sve uplaćivala net kad sam išla kod babe samo kad bih mogla da odgovorim na poruku. ruke mi se osušile da Bog da.

otkad se nisam dopisivala sa nekim ono da se smijem kad mi posalje neku slatku poruku da jedva cekam da se javi da ce peckamo ovo ono no sam ko baba neka postala nista me ne moze zainteresovat dabogda crkla ja

Nosiš ga 9 meseci, rodiš, gajiš od 3,5 kg mesa, prodješ sve lepote i sekiracije ovog sveta i dočekaš da može da ode po pivo a oni ga vrate, kaže ne prodaju maloletnicima! $\mathrm{Pa}$ crkli dabogda 
Kletva se u primjerima koji se mogu okarakterizirati kao pričanja o životu javlja i kao pokretački motiv zgode o kojoj se pripovijeda.

Krenem da odgovorim: "E crko dabogada" i onda ne znam da li se piše Da bog da ili Da Bog da ili Dabogda i tako ti preživiš iako si smeće

Kad sam davno nekad radila u Domu zdravlja, došao je muž moje starije koleginice i zamolio me da je pozovem. Rekla sam: Dragice, traži te crko dabogda, ...ja mu za drugo ime nisam znala.

Daleko je veći broj primjera u kojima se ludička kletva javlja kao iskaz u okviru drugih folklornih žanrova (85\%) nego kao samostalni iskaz (14\%), što upućuje na činjenicu, uzevši u obzir i način na koji je uvrštena u druge žanrove, da je njezina uloga u diskursu internetskih žanrova stvaranje humorne situacije ili zapleta radnje. Razvidno je da ludička kletva kao iskaz u okviru drugih folklornih žanrova slijedi funkciju klasične koja također često ima ulogu u zapletu radnje (usp. Nikolić 2010: 149).

\section{ŽANROVSKA ANALIZA U KONTEKSTU INTERNETSKIH ŽANROVA}

Kako bi se zornije moglo prikazati kako se žanr kletve aktualizira u kontekstu međusobno povezanih internetskih žanrova, aktualizacija će se objasniti na jednom primjeru, a sv ostali se analogno ponašaju. Prvo korisnik društvene mreže Twitter napiše kakav status, tvit, poznat i po nazivu mikroblog (usp. Zappavigna 2017: 201), u koji je uključena i kletva. Primjerice:

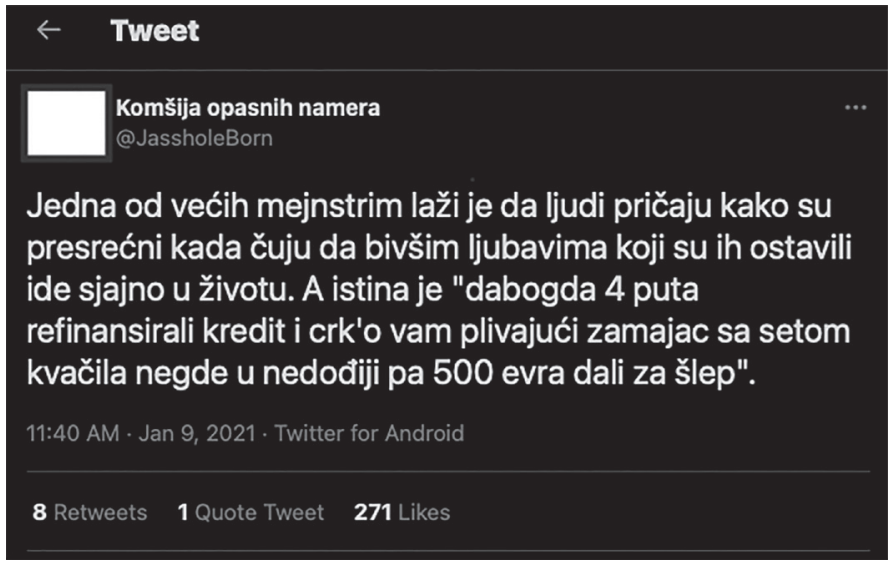

Slikovni prilog 1. Primjer tvita s društvene mreže Twitter ${ }^{15}$

${ }^{15}$ https://twitter.com/JassholeBorn/status/1347855716929953794?s=20 (pristup 4. 4. 2021.). 
Nakon toga, ako ga administratori mrežne stranice Mudrolije sa Twittera prepoznaju kao dovoljno zanimljivog, vizualno ga urede prema postojećem obrascu koji se ne mijenja i objave ga na svom korisničkom profilu na društvenim mrežama Facebook i/ili Instagram gdje je dostupan drugim korisnicima za interakciju.

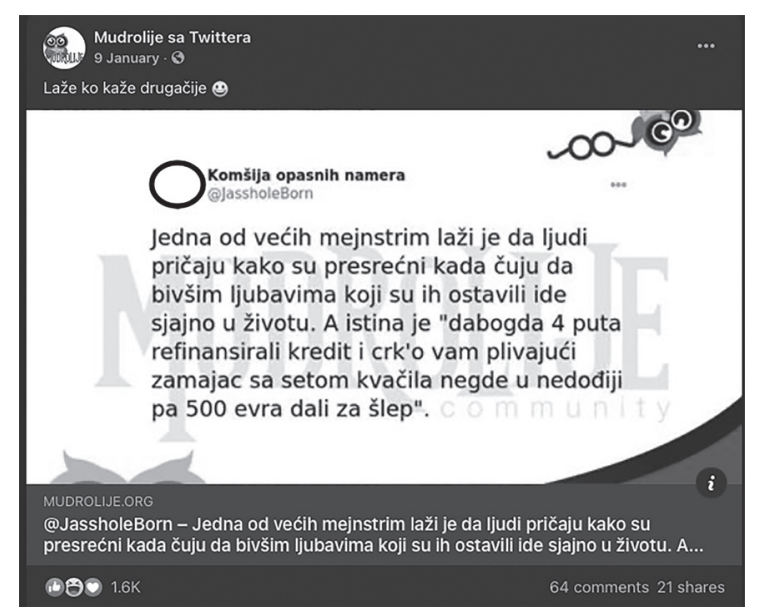

Slikovni prilog 2. Primjer uređenog tvita za stranicu Mudrolija sa Twittera ${ }^{16}$

Interakcijom korisnika koji ga komentiraju, dijele, označavaju druge korisnike u komentarima (engl. tag) i označavaju uređeni tvit i komentare na njega sa "sviđa mi se" (engl. like) razvija se internetski multimedijalni posredovani narativni žanr podijeljenih priča (engl. shared stories) (usp. Page 2018). Ovakve su prakse odlika komunikacije na društvenim mrežama općenito, no žanrom podijeljenih priča čini ih uža tematska orijentiranost međusobno povezanih korisnika koji pripadaju jednoj virtualnoj zajednici što reprezentira zajedničke idejne stavove njezinih korisnika. Iz toga se razloga žanr podijeljenih priča na društvenim mrežama uglavnom javlja na tzv. community pages (ibid.: 85), poput profila Mudrolije sa Twittera na koje je usmjereno ovo istraživanje, a na kojima se okupljaju istomišljenici koji kao sukazivači (engl. co-tellers) zajednički stvaraju podijeljene priče (ibid.: 101-120). Žanr podijeljenih priča nastao je na temelju malih priča (engl. small stories) što, primjerice, nastaju pri svakodnevnom ležernom razgovaranju, komentiranju situacije koja se trenutno događa17 i u kojima se narativu pristupa društveno interakcijski (engl. social interactional approach SIA) (usp. de Finna i Georgakopoulou 2008; Marković 2012: 137-138; Georgakopoulou 2015; 2019; Page 2018: 9). Karakteristike malih priča

\footnotetext{
${ }^{16}$ https://www.facebook.com/MudrolijeCommunity/posts/3925788780817261 (pristup 4. 4. 2021.).

17 “Pobornici istraživanja 'malih priča' pričom vrijednom istraživanja kao bogatu informacijama o kulturi smatraju i onu koja, primjerice, pripovijeda o događajima koji su u tijeku, budućim ili hipotetskim događajima, dijeljenim događajima, aluzijama na prijašnja pričanja pa čak i odgode ili odbijanje pričanja. Priče su to o recentnim događajima ("jutros", "sinoć" i sl.) ili događajima koji su još u tijeku i jednostavno zadovoljavaju potrebu da podijelimo ono što se upravo dogodilo, da prokomentiramo situaciju ili slično. One mogu biti, kako se to kolokvijalno kaže i ‘ni o čemu’” (Bamberg i Georgakopoulou prema Marković 2018: 137-138).
} 
prepoznate su u mnogim (kratkim) komentarima internetskih korisnika na istu temu koji zajednički kao sukazivači stvaraju podijeljene priče. Žanr podijeljenih priča teorijski je razvijen oslanjajući se i uz koncept vezivanja (engl. bonding) (usp. Zappavigna 2014, 2017; Page 2018: 83-100) kojim se objašnjava povezanost internetskih korisnika i njihov osjećaj pripadnosti virtualnim zajednicama na društvenim mrežama bez izravne komunikacije, tj. koje prakse ih povezuju. Michele Zappavigna (2017: 216) vezivanje objašnjava pojmom "ambijentalna pripadnost" (engl. ambient affiliation), tj. društveno povezivanje u kojem internetski korisnici kao pojedinci ne moraju nužno izravno komunicirati kako bi sudjelovali u određenim vrstama "pripadanja”. Ruth Page (2018: 96-100) vezivanje korisnika na društvenoj mreži Facebook objašnjava i kroz opciju "sviđa mi se"18 što ukazuje i na zauzimanje stavova o pojedinoj temi unutar stranice. Konceptom vezivanja korisnici se promatraju kao zajednica istomišljenika, a tematska okosnica stranice Mudrolije sa Twittera je humor, što ima važnu ulogu u stvaranju grupa solidarnosti i identiteta u računalno posredovanoj komunikaciji (usp. Baym 2004; Vásquez 2019: 30; Yus 2021a: 1).

Podijeljene priče pojavljuju se u razgovornom kontekstu, a karakterizira ih: 1) pripovijedanje podijeljeno između više govornika; 2) intertekstualne reference koje povezuju zajedničke tekstove (tagiranje i hashtag); 3) distribuirana linearnost, pri čemu narativni sadržaj nastaje i reproducira se u više dijelova i 4) pretpostavka zajedničkih uvjerenja (usp. Page 2018: 18).

Na konkretnom primjeru razvidno je da je stranicu Mudrolije sa Twittera na Facebooku označilo sa sviđa mi se više od 620 tisuća korisnika, a analizirani uređeni tvit više od 1600 korisnika, te da je 64 puta komentiran i 21 put podijeljen.
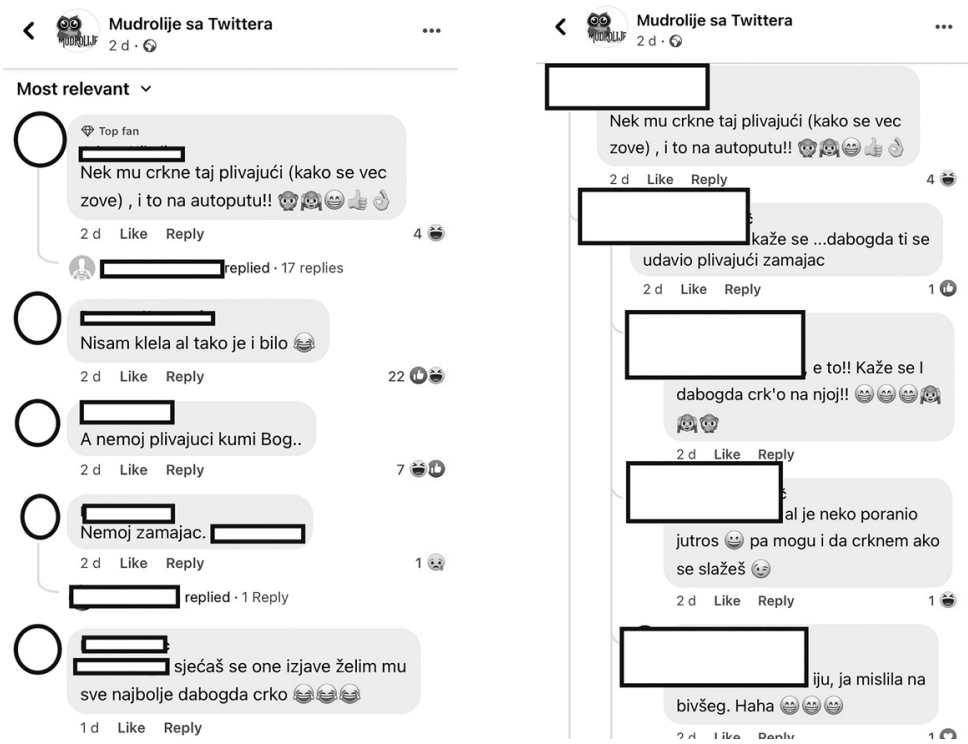

Slikovni prilog 3. Primjer interakcije korisnika na objavu s Mudrolija sa Twittera ${ }^{19}$

\footnotetext{
${ }^{18}$ Opcija "sviđa mi se" odnosi se i na sviđanje stranice i pojedine objave.

${ }^{19}$ https://www.facebook.com/MudrolijeCommunity/posts/3925788780817261 (pristup 4. 4. 2021.).
} 
Na ovom je primjeru razvidno da interakciju korisnika potiče i kletva spomenuta u objavi, na koju se korisnici nadovezuju raznim komentarima te tako dalje posredovano razvijaju narativnost (podijeljene) priče, a među njima su i oni koji, potaknuti inicijalnom, sadrže nove kletve ili komentare koje aludiraju na kletveni kontekst.

Nek mu crkne taj plivajući (kako se već zove) i to na autoputu

Kaže se ...dabogda ti se udavio plivajući zamajac

E to! Kaže se i dabogada crk'o na njoj!

Nisam klela al tako je i bilo

Sjećaš se one izjave želim mu sve najbolje dabogda crko

Na ovim je primjerima najočitije da je riječ o ludičkoj kletvi koja nema namjeru izricanja zla, već stvaranje humorna učinka, što je razvidno i korištenjem emotikona, a njezina uloga u podijeljenoj priči analogna je ulozi kletve u usmenoj književnosti gdje služi kao efektan (i ekonomičan) način povezivanja određenih segmenata radnje (usp. Detelić i Delić 2012: 32).

\section{IZVEDBENI KONTEKST}

Što se tiče izvedbenog konteksta, zamijećena su dva načina na koje se kletva aktualizira u humornom diskursu internetskih žanrova, a riječ je o aludiranju na kletvu (48\% primjera) i izricanju kletve (51\% primjera). Podjednak omjer aluzivne i izrečene kletve također ukazuje na činjenicu da je riječ o ludičkim primjerima koji nemaju namjeru/želju izricanja zla jer se izricanje, kao bitna odrednica usmenoretoričkoga žanra kletve, javlja samo u polovici primjera. lako se i u usmenoj književnosti javljaju pretpostavljene, tzv. hipotetične kletve (usp. Detelić i Delić 2012: 41), bitna razlika od aluzivnih u digitalnom folkloru je humoristična priroda. U aluzivnim se primjerima humornim diskursom samo ukazuje na kletveni kontekst ("I ja sam nečije 'crkla dabogda”; “'Želim ti puno sreće s njim' / lliti, što bi vi žene rekle: / CRKLI DABOGDA OBOJE”; “Kad vam žena kaže uživaj, to najčešće znači crko dabogda"). Sklonije su im pripovjedačice, tj. 68\% takvih primjera napisale su tviterašice, a 31\% tviteraši. U drugoj skupini primjera kletva je nekome direktno izrečena u šaljivom kontekstu ("al kad čujem još uvek sam ranjiva posle raskida pa ranio te albatros kljunom u čelo dabogda"; "Ništa gore kad muvaš curu izvedeš je na piće a dođe onaj idiot što prodaje ruže stane iznad tebe i ti moraš kupit ružu od 5 E dabogda crko i on i ruža"). Takvim su iskazima također sklonije pripovjedačice, i to u 61\% primjera.

Zanimljivo je vočiti i način upotrebe velikih i malih slova $u$ analiziranim primjerima jer ukazuju na kletvi imanentnu afektivnost u govornom činu. U pisanoj komunikaciji na internetu uvriježeno je pravilo da kada osoba želi naglasiti svoju ljutnju, tj. ukazati da bi u realnom govornom činu vikala, koristit će velika slova (usp. Yus 2011: 164). Zamjećuje se da korisnici često koriste velika slova u situacijama kada pripovjedač ili lik izriču kletvu ili na nju aludiraju, a u ostatku teksta koriste mala slova. Primjerice: 
1) "Želim ti puno sreće s njim"

liti, što bi vi žene rekle:

CRKLI DABOGDA OBOJE

2) “Uživaj ;)" umesto "ZELIM TI SVE NAJGORE DABOGDA TE KACAVENDA PIPKAO

KARLEUSA TI PEVALA VUCIC TE HAPSIO UMRI” je krace i elegantnije

3) e moram ti nešto reći

reci

ma joj ništa

DABOGDA CRK'O GOVORI BUBREG ĆU TI IZVADITI

4) pusac: *zapali cigaretu*

nepusac: *ne reaguje uopste*

bivsi pusac: DA BOG DA SE UGUSIO U TAJ DIM PICKA TI MATERINA

Prema ovim je primjerima razvidno da je kletva u kolektivnom pamćenju vezna uz afektivni govorni čin, što se u digitalnom obliku pokušava slijediti, iako ne dosljedno i na način koji dopuštaju okolnosti u mrežnom pisanom komuniciranju.

\section{SADRŽAJNA ANALIZA}

Sadržajna analiza provest će se po uzoru na metodologiju analize kletve u usmenoj epici ${ }^{20}$ Davora Nikolića (2010) s određenim modifikacijama vezanim uz osobitosti analiziranog korpusa. Ludičke kletve će se sadržajno analizirati prema kriteriju autora, pripovjedača, glasa izricatelja, odnosa adresanta i adresata, subjekta i objekta te tematsko-motivskog razloga izricanja kletve. U svim kriterijima analizirat će se i rodni odnosi da bi se uvidjelo koji je rod skloniji izricanju ludičkih kletvi u digitalnom folkloru te u kojem kontekstu, a s ciljem ukazivanja na činjenicu da se ludička kletva i sadržajno oslanja na klasičnu. Stereotipno je mišljenje da žene češće kunu nego muškarci (usp. Radulović 2007: 143; Nikolić 2010: 151) i u usmenoj se tradiciji djevojačka kletva, uz majčinu i kumovu, smatra jednim od njezinih najtežih oblika (usp. Živković 1985: 336; Dragić 2008: 81-83; Popović 2010: 343; Detelić i Delić 2012).

U svim primjerima pripovjedači su i autori duhovitih tekstova, tj. internetski korisnici s društvene mreže Twitter koji su na tvitu potpisani pseudonimom i/ili korisničkim imenom, poput Bezkonzervansna, Šerlokova ili Zadnji žmurim. Što se tiče rodnih odnosa, 65\% je pripovjedačica, a $34 \%$ je pripovjedača. S obzirom na to da je analizirani humorni diskurs nastao od osobnih tvitova, većina ih prenosi kakav subjektivni, osobni doživljaj te je češće glas izricatelja i pripovjedač (80\%), a u manjem je broju primjera izricatelj kletve lik (19\%). Kada je glas izricatelja pripovjedač, riječ je o 64\% adresantica i 35\% adresanata. Kada

${ }^{20}$ Davor Nikolić analizirao je kletvu u usmenoj i pisanoj epici, no u ovom se radu neće govoriti o suodnosima ludičke kletve u digitalnom folkloru s onom u pisanoj epici, već je rad usmjeren na suodnos ludičke kletve s kletvom u usmenoj tradiciji. 
je glas izricatelja lik, u 66\% primjera riječ je o adresanticama, a u ostalih 33\% ne može se odrediti spol adresanta ("I ja sam nečije 'crkla dabogda"). Što se tiče adresata, u 48\% primjera im se ne može odrediti rod jer je kletva opće formulirana ("Ovima što pokupiše sve jestivo sa rafova da poručim samo jedno... Dabogada vam crko frižider."). U ostalim primjerima je $27 \%$ muških i $24 \%$ ženskih adresata, s tim da je u $12 \%$ primjera riječ o autoadresaciji i tada su adresanti samo žene. Kada je riječ o muškim adresantima, kletva je najčešće upućena nepoznatim adresatima (50\%), zatim muškim (30\%), te ženskim (20\%). Kada pak govorimo o adresanticama, omjer je nešto drukčiji nego u adresanata te je kletva također najčešće upućena nepoznatom adresatu (42\%), zatim slijede adresati suprotnoga spola (30\%), autoadresacija (19\%) i na koncu je najmanje kletvi upućeno adresatima istog spola (7\%).

Što se tiče subjekata kletve, tj. onih koji bi je po adresantovu izricanju morali izvršiti, te objekata, tj. one/ono što kletva treba stići (usp. Nikolić 2010: 155), na analiziranim je primjerima razvidno da kletve nisu ozbiljne, tj. da njihova funkcija nije nanijeti zlo, već imitirajući kletveni žanr nasmijati korisnika. Zbog imitiranja žanra kletve najčešćim subjektom može se smatrati Bog jer se često javljaju kletvi imanentne formulacije da Bog da (5 puta) ili njezina sraslica dabogda (33 puta). Oba primjera - i sveza riječi i konektor - izvrsno ukazuju na to da iako su primjeri kletve ludički, u sebi čuvaju ostatke vjerovanja u magijsku moć riječi i da je kletva upisana u kolektivnu memoriju kao magijski žanr. Shodnije je ukazati na ostale subjekte u ludičkim kletvama po kojima je razvidno da je riječ o šaljivim tekstovima koji nemaju namjeru izravne želje zla nekome, te se kao subjekti javljaju osobe iz političkog i javnog života Srbije (“'Uživaj';) umesto 'ZELIM TI SVE NAJGORE DABOGDA TE KACAVENDA PIPKAO KARLEUSA TI PEVALA VUCIC TE HAPSIO UMRI' je krace i elegantnije") ili ptica albatros ("al kad čujem još uvek sam ranjiva posle raskida pa ranio te albatros kljunom u čelo dabogda"). Ironiziranje žanra kletve najjasnije se primjećuje na primjeru objekata kletvi poput: čovjeka koji prodaje ruže osobama koje su na ljubavnom spoju i same ruže ("Ništa gore kad muvaš curu izvedeš je na piće a dođe onaj idiot što prodaje ruže stane iznad tebe i ti moraš kupit ružu od 5 E dabogda crko i on i ruža"), prodavača koji maloljetniku ne žele prodati alkohol ("Nosiš ga 9 meseci, rodiš, gajiš od 3,5 kg mesa, prodješ sve lepote i sekiracije ovog sveta i dočekaš da može da ode po pivo a oni ga vrate, kaže ne prodaju maloletnicima! Pa crkli dabogda"), hladnjaka osoba koje su previše kupovale u vrijeme početka koronakrize ("Ovima što pokupiše sve jestivo sa rafova da poručim samo jedno... Dabogada vam crko frižider"), bankovnih kredita bivših ljubavnika i izmišljenih automobilskih dijelova ("Jedna od većih mejnstrim laži je da ljudi pričaju kako su presrećni kada čuju da bivšim ljubavima koji su ih ostavili ide sjajno u životu. A istina je 'dabogda 4 puta refinansirali kredit i crk'o vam plivajući zamajac sa setom kvačila negde u nedođiji pa 500 evra dali za šlep'”), Kineza koji je prema urbanoj legendi pojeo šišmiša i uzrokovao pojavu koronavirusa ("Da ima neki vremenoplov točno bi se vratio do onog nultog Kineza, dao mu 2 kg slanine i luka i rekao 'najedi se usro se dabogda. Jebo te šišmiš!"), osoba koje nekome nisu čestitali rođendan ("Zamara me da se javljam svima i zahvaljujem oko mog rodjendana al takodje dabogda poginuo tko ne cestita") i slično. 
Dakle, prema objektu na kojem se treba manifestirati zlo izrečeno kletvom razvidno je da nije riječ o ozbiljnim kletvama kojima se nekome želi zlo, već o njihovim humorističnim inačicama.

Pri tematsko-motivskoj analizi razloga izricanja ludičke kletve ili aludiranja na kletveni kontekst, zamjećuje se da je često riječ o sličnim razlozima zbog kojih se kletva izriče i u usmenoj tradiciji, tj. ona je rezultat nekog konflikta ili neriješenog problema u komunikaciji i uopće socijalnom odnosu između dvije osobe (usp. Radulović 2007: 138), no kontekst je humoristične prirode. Najviše je kletvi izrečeno zbog problema u ljubavnim (partnerskim) odnosima (41\%), a takve kletve su u digitalnom folkloru sklonije izreći žene (64\% primjera), što se može povezati s utjecajem djevojačke kletve u usmenoj tradiciji ("Dabogda ti trebala k’o punjač za android."). Zamijećen je i oblik u kojem muški pripovjedač aludira na stereotip da su izricanju kletvi sklonije žene (“Želim ti puno sreće s njim' / liti, što bi vi žene rekle: / CRKLI DABOGDA OBOJE"). Po učestalosti ih slijede one izrečene u ljutnji (26\%) i svađi (10\%), kojima su također sklonije žene (60\% primjera), a i tada se može naslutiti da je često riječ o ljubavnim razmiricama, iako se to ne može pouzdano tvrditi ("- Jesi ljuta? / - Nisam, crkni."; "I ja sam nečije 'crkla dabogda”). Slijede ih tzv. antikletve u 9\% primjera ("Dabogda svi na more išli ove godine!"), kojima su također sklonije pripovjedačice (75\%). Zatim slijede $u$ istoj mjeri one izrečene iz drugih razloga (5\%) i izrečene iz zavisti u 5\% primjera (“- KOLIKO VAM JE PRSLUK IZ IZLOGA? / 16900 dinara / HVALA DOVIĐENJA CRKLA DA BOG DA RUŽNA TI JE KOSA DEČKO TE VARA"), te na koncu jedan primjer (2\%) majčine kletve ("Od svih majčinih reči upućenih mi plašim se samo da me ne stignu one “Dabogda ti deca bila ko ti meni”).

\section{ULOGA LUDIČKE KLETVE U HUMORNOM DISKURSU INTERNETSKIH ŽANROVA}

Prema žanrovskom, izvedbenom i sadržajnom opisu tzv. ludičke kletve u humornom diskursu internetskih žanrova, zaključiti se može da je njezina uloga prvenstveno stvaranje humorna učinka. Humorni učinak $u$ analiziranim primjerima postiže se na dva načina čija je poveznica nesklad ili proturječnost, a najčešće je riječ o ironijskom neskladu na razini žanra i razrješenju inkongruentnosti na razini humorističnog teksta. Već imitiranje žanra kletve na humorističan način ukazuje na ironiji tipičan bilo kakav oblik nesklada ili kontrasta koji se temelji na protivljenju, preokretu, inverziji, negaciji značenja ili proturječju između izrečenog i onoga što se (antitetički) misli (usp. Dynel 2018: 91), a takav je ironijski pristup humornom diskursu čest u računalno posredovanoj komunikaciji (usp. Alamán i Mancera Rueda 2016). U kolektivnom pamćenju kletva je verbalni magijski žanr koji "adresatu treba donijeti nesreću, bolest pa i smrt" (Nikolić 2019: 21), a u računalno posredovanoj komunikaciji na društvenim mrežama njezina je uloga često suprotna onoj koja se žanrom kletve pretpostavlja ("Dabogda svi na more išli ove godine!"). Sličan nesklad javlja se i u strukturi humorističnih tekstova u kojima se humorni učinak postiže razrješenjem 
inkongruentnosti ${ }^{21}$ (usp. Attardo 1994: 47-49; Oring 2016: 16-33) što je čest oblik stvaranja humorna učinka u internetskim žanrovima (usp. Dynel 2016; Yus 2021b; Predojević 2021a, 2021b). Kletva se u humorni diskurs internetskih žanrova najčešće uvrštava kao efektna posljednja rečenica (68\% primjera) ili unutar teksta 22 (23\% primjera) gdje stvara scenarijske opreke (usp. Attardo 1994: 200; Marković 2019: 171) s tekstom u koji se uključuje, a time i osjećaj neskladnosti, proturječnosti ili inkongruentnosti. Uvrštavanjem žanra kletve u humorni diskurs ("Ja često ćutim u diskusijama jer je društveno prihvatljivije da misle da sam mutava nego da govorim 'dabogda umro' svakih 36 sekundi"; "od osvajanja sveta kada ustanem do dabogda se ne probudila uvece") ili imitiranjem žanra kletve upotrebom imanentnih joj formulacija poput konektora dabogda ("Ko voli snijeg dabogda mu u kući pado"), aludira se na kletveni diskurs koji u kolektivnom pamćenju podrazumijeva izricanje zla, a primjenjuje se na neočekivano iskustvo čime dolazi do humorna sudara.

\section{ZAKLJUČNO}

Zaključno se mogu sumirati sličnosti i razlike između kletve u usmenoj tradiciji i internetskim žanrovima, iako ih valja uzeti s određenim odmakom s obzirom na manji broj analiziranih primjera koji je uvjetovan usmjerenošću na jednu mrežnu stranicu. Osnovna je razlika da se u internetskim žanrovima uglavnom pojavljuju primjeri ludičke kletve (93\% primjera), tj. one izrečene u šali i bez vjerovanja u magijsku moć riječi. Njezina je osnovna uloga u diskursu internetskih žanrova stvaranje humorne situacije na što upućuje i činjenica da se češće javlja kao iskaz u okviru drugih folklornih žanrova (85\%), gdje ima ulogu stvaranja osjećaja neskladnosti, proturječnosti ili inkongruentnosti čime dolazi do humorna sudara. U (proto)narativnoj strukturi humornih tekstova ludička kletva ima sličnu ulogu kao i klasična u usmenoj književnosti, tj. služi u zapletu radnje ili kao efektan (i ekonomičan) način povezivanja njezinih određenih segmenata. Da njezina svrha nije nanijeti zlo upućuje i činjenica da se uz izrečene kletve javljaju i aluzivne, kojima se samo želi aludirati ili pozvati na kletveni kontekst koji se ironizira. Tomu efektu pridonose i prikazani subjekti i objekti kletve. Najčešće je prepoznajemo po konektoru dabogda ili svezi riječi "da Bog da" te izraženoj afektivnosti govornika koja se u internetskim žanrovima iskazuje korištenjem velikih slova i uskličnih rečenica. lako ludička kletva nema istu namjeru kao ozbiljna, njezine tematsko-motivske osobitosti nastale su po uzoru na ozbiljnu, tj. u njima se prepoznaju slični tematsko-motivski sadržaji poput ljubavnih odnosa, srdžbe, zavisti i sl., ali i tipovi kletvi, poput djevojačke koja čini $24 \%$ korpusa, a javlja se i jedan primjer majčine kletve. U usmenoj epici kletvu češće izriču likovi (94\%) (usp. Nikolić 2010: 150), a u analiziranom korpusu likovi su izricatelji kletve u svega 19\% primjera. Pretpostavlja se

${ }^{21}$ Elliott Oring (2016: 16-33) razrješenje inkongruentnosti naziva odgovarajuća inkongruentnost (engl. appropriate incongruity).

${ }^{22} \mathrm{U}$ ostalih 6\% primjera uvrštava se postupkom parafraziranja umjesto ključnih riječi aforizama, a u $2 \%$ primjera kletvom započinje tekst. 
da je razlog tomu činjenica da je u digitalnom folkloru autor uvijek i pripovjedač, te zbog toga što su primjeri nastali od osobnih statusa u kojima je naglašeno osobno iskustvo, a ne ono kolektivno što su ga oblikovali mnogi kazivači kao što je to imanentno usmenoj književnosti. Govoriti o rodnim odnosima adresanata koji su skloniji izreći kletvu u usmenoj književnosti je komplicirano i ovisi o analiziranom korpusu. ${ }^{23}$ Ovim je radom potvrđeno stereotipno mišljenje da žene češće kunu nego muškarci (usp. Radulović 2007: 143; Nikolić 2010: 151), jer se češće javljaju kao autorice ili pripovjedačice (65\%), kada je glas izricatelja pripovjedač (64\%) i kada je to lik (66\%), te u primjerima gdje se kletva izriče (61\%) i u kojima se na nju aludira (68\%), ali i u većini analiziranih tematsko-motivskih razloga izricanja kletve.

Aktualiziranjem klasičnog žanra kletve u sklopu internetskih žanrova, zamjećuje se da se skoro u potpunosti gubi njezina prvotna magijska funkcija i želja izricatelja kletve da nekoga stigne zlo, tj. njezina je magijska uloga deritualizirana (usp. Kádár i Szalai 2019: 3) te služi kao element u stvaranju humorna učinka. Humorni učinak u ovim primjerima zasniva se na ironiziranju žanra kletve, njegovu uvrštavanju u humorni diskurs i neskladnoj uporabi konektora dabogada koji u kolektivnoj memoriji evocira želju za izricanja zla, no primjenjuje se na posve neočekivano iskustvo čime se postiže humorni učinak. Na koncu, prema uzoru na englesku literaturu o kletvi (Danet i Bogoch 1992: 134-135; Culpeper i Semino 2000: 103; Archer 2010: 398), terminom ludička kletva u digitalnom folkloru mogu se označiti suvremeni šaljivi oblici kletvi što se javljaju kao samostalan iskaz i kao iskaz u okviru drugih žanrova, čija je osnovna uloga stvaranje humorna učinka u diskursu internetskih žanrova, te iako su izrečene u šali i bez adresantove želje za izricanjem zla, u sebi čuvaju ostatke vjerovanja u magijsku moć riječi što je razvidno korištenjem kletvi imanentnih formulacija, a prije svega konektora dabogda.

\section{LITERATURA I IZVORI}

Ajdačić, Dejan. “O kletvi u usmenoj književnosti”. Dostupno na: https://www.rastko.rs/knjizevnost/nauka_knjiz/dajdacic-kletva.html (pristup 5. 2. 2021.).

Alamán, Ana Pano i Ana Mancera Rueda. 2016. "Humor and Advertising in Twitter. An Approach from the General Theory of Verbal Humor and Metapragmatics". U Metapragmatics of Humor. Current Research Trends. Leonor Ruiz-Gurillo, ur. Amsterdam, Philadelphia: John Benjamins Publishing Company, 35-56. https://doi.org/10.1075/ivitra.14.03ala

${ }^{23}$ Primjerice, prema korpusu koji je analizirao Davor Nikolić (2010: 153) češći su adresanti muški likovi (70\% : 30\%), a i sam autor pretpostavlja da je takav rezultat s obzirom na narav epskog korpusa i tematsko-motivskog svijeta koji on podrazumijeva. Lidija Radulović (2007: 143) navodi da je u folklornoj građi 19. i 20. stoljeća kletva uglavnom pripisivana ženama. Mirjana I. Detelić i Lidija D. Delić (2012) ne govore o rodnim odnosima, ali u svojoj studiji ukazuju na težinu kletvi koje su izrekle uglavnom žene na korpusu od 1500 epskih pjesama. Njihovi zaključci odgovaraju kritičkoj refleksiji o žanru kletve gdje se napominje da su majčine i djevojačke jedne od najtežih oblika kletvi (usp. Živković 1985: 336; Dragić 2008: 81-83; Popović 2010: 343). 
Archer, Dawn. 2010. "Speech Acts". U Historical Pragmatics. Andreas H. Jucker i Irma Taavitsainen, ur. Berlin, New York: De Gruyter Mouton, 379-418.

Attardo, Salvatore. 1994. Linguistic Theories of Humor. Berlin, New York: Mouton de Gruyter.

Badurina, Lada i Ivo Pranjković. 2019. "O kletvi i psovci”. U Njegoševi dani, 7. Tatjana Đurišć-Bečanović, ur. Nikšić: Filološki fakultet Nikšić, 219-230.

Baran, Anneli. 2012. "Visual Humor on the Internet". U Estonia and Poland. Creativity and Tradition in Cultural Communication. Liisi Laineste, Dorota Brzozowska i Władysław Chłopicki, ur. Tartu: ELM Scholarly Press, 171-186.

Baym, Nancy K. 2004. "Izvedbe humora u računalno posredovanoj komunikaciji". U Etnografije interneta. Iva Pleše i Reana Senjković, ur. Zagreb: Institut za etnologiju i folkloristiku, 161-193.

Bošković-Stulli, Maja. 1988. "Telling About Life (on Questions of Contemporary Oral Literary Genres)”. Narodna umjetnost Special Issue/2: 11-41.

Botica, Stipe. 2005. “Trajno živa usmenoknjiževna baština”. Narodna umjetnost 42/2: 127-154.

Botica, Stipe. 2013. Povijest hrvatske usmene književnosti. Zagreb: Školska knjiga.

Brozović, Domagoj. 2012. "Od ironije do aforizma”. Umjetnost riječi 56/1-2: 43-58.

Culpeper, Jonathan i Elena Semino. 2000. "Constructing Witches and Spells. Speech Acts and Activity Types in Early Modern England". Journal of Historical Pragmatics 1/1: 97-116. https://doi. org/10.1075/jhp.1.1.08cul

Danet, Brenda i Bryna Bogoch. 1992. "Whoever Alters This, May God Turn His Face from Him on the Day of Judgment'. Curses in Anglo-Saxon Legal Documents". The Journal of American Folklore 105/416: 132-165. https://doi.org/10.2307/541083

Dayter, Daria. 2016. Discursive Self in Microblogging. Speech Acts, Stories and Self-praise. Amsterdam, Philadelphia: John Benjamins Publishing Company. https://doi.org/10.1075/pbns.260

De Fina, Anna i Alexandra Georgakopoulou. 2008. "Analysing Narratives as Practices." Qualitative Research 8/3: 379-87. https://doi.org/10.1177/1468794106093634

Detelić, Mirjana I. i Lidija D. Delić. 2012. “Modelativni potencijal kletve u usmenoj epici”. Poznańskie Studia Slawistyczne 3: 29-43. https://doi.org/10.14746/pss.2012.3.1

Dragić, Marko. 2008. Poetika i povijest hrvatske usmene književnosti. Split: Filozofski fakultet Sveučilišta u Splitu.

Dynel, Marta, 2016. “I Has Seen Image Macros!' Advice Animals Memes as Visual-Verbal Jokes”. International Journal of Communication 10/29: 660-688.

Dynel, Marta. 2018. Irony, Deception and Humour. Seeking the Truth about Overt and Covert Untruthfulness. Boston: De Gruyter Mouton. https://doi.org/10.1515/9781501507922

Endstrasser, Vilko. 2020. Mali oblici. Promišljanje žanra. Zagreb: Institut za etnologiju i folkloristiku.

Georgakopoulou, Alexandra. 2015. "Small Stories Research". U The Handbook of Narrative Analysis. Anna De Fina i Alexandra Georgakopoulou, ur. Somerset: John Wiley \& Sons, Incorporated, 255-271. Dostupno na: https://ebookcentral.proquest.com/lib/uniba-ebooks/reader.action?do$c \mid D=3563935 \& p p g=6$ (pristup 7. 4. 2021.). https://doi.org/10.1002/9781118458204.ch13

Georgakopoulou, Alexandra. 2019. "Sharing the Moment as Small Stories. The Interplay Between Practices \& Affordances in the Social Media-Curation of Lives". U Storytelling in the Digital Age. Anna De Fina i Sabina Perrino, ur. Amsterdam: John Benjamins Publishing, 105-127. https://doi.org/10.1075/ bct.104.06geo

Giltrow, Janet i Dieter Stein. 2009. "Genres in the Internet. Innovation, Evolution, and Genre Theory". U Genres in the Internet. Issues in the Theory of Genre. Janet Giltrow i Dieter Stein, ur. Amsterdam: John Benjamins Publishing Company, 1-26. https://doi.org/10.1075/pbns.188.01gil 
Heyd, Theresa. 2009. "A Model for Describing 'New' and 'Old' Properties of CMC Genres. The Case of Digital Folklore". U Genres in the Internet. Issues in the Theory of Genre. Janet Giltrow i Dieter Stein, ur. Amsterdam: John Benjamins Publishing Company, 239-262. https://doi.org/10.1075/pbns.188. 10hey

Jay, Timothy. 1992. Cursing in America. A Psycholinguistic Study of Dirty Language in the Courts, in the Movies, in the Schoolyards and on the Streets. Philadelphia: John Benjamins Publishing Company. https://doi.org/10.1075/z.57

Kádár, Dániel Z. i Andrea Szalai. 2019. “The Socialisation of Interactional Rituals. A Case Study of Ritual Cursing as a Form of Teasing in Romani". Pragmatics 30/1: 15-39. https://doi.org/10.1075/ prag.19017.kad

Kitz, Anne Marie. 2014. Cursed Are You! The Phenomenology of Cursing in Cuneiform and Hebrew Texts. Winona Lake, Indiana: Eisenbrauns. https://doi.org/10.1515/9781575068749

Laineste, Liisi. 2016. "From Joke Tales to Demotivators. A Diachronic Look at Humorous Discourse in Folklore". Traditiones 45/3: 7-25. https://doi.org/10.3986/Traditio2016450302

Laineste, Liisi i Piret Voolaid. 2016. "Laughing Across Borders. Intertextuality of Internet Memes”. The European Journal of Humour Research 4/4: 26 -49. https://doi.org/10.7592/EJHR2016.4.4.laineste

Lemac, Tin. 2011. "Problem i funkcija ironije u pjesničkom pismu Jozefine Dautbegović". Nova Croatica 5 [35]/5[55]: 99-112.

Litovkina, Anna T. 2015. "Anti-proverbs". U Introduction to Paremiology. A Comprehensive Guide to Proverb Studies. Hrisztalina Hrisztova-Gotthardt i Melita Aleksa Varga, ur. Varšava, Berlin: De Gruyter Open Ltd, 326-352.

Marković, Ivan. 2019. Uvod u verbalni humor. Zagreb: Disput.

Marković, Jelena. 2012. Pričanja o djetinjstvu. Životna priča u svakodnevnoj komunikaciji. Zagreb: Institut za etnologiju i folkloristiku.

McNeill, Lynne S. 2013. "And the Greatest of These Is Tradition. The Folklorist's Toolbox in the Twenty-First Century". U Tradition in the Twenty-First Century. Locating the Role of the Past in the Present. Trevor J. Blank i Robert Glenn Howard, ur. Logan: Utah State University Press, 174-185. https:// doi.org/10.7330/9780874218992.c07

Mudrolije sa Twittera. Dostupno na: https://www.instagram.com/mudrolijesatwittera/?hl=hr (pristup 4. 4. 2021.). i https://www.facebook.com/MudrolijeCommunity (pristup 4. 4. 2021.).

Nikolić, Davor. 2010. "Struktura i funkcija kletvi u usmenoj i pisanoj epici". Narodna umjetnost 47/2: 147-162.

Nikolić, Davor. 2015. "Mali, sitni, jednostavni, govornički ili jednostavno - retorički. Povijest naziva i koncepata usmenoretoričkih žanrova u hrvatskoj folkloristici". Narodna umjetnost 52/2: 163-178. https:// doi.org/10.15176/vol52no208

Nikolić, Davor. 2017. “U početku bijaše kletva... Zapisi usmenoretoričkih žanrova i njihove interferencije s djelima pisane književnosti u dopreporodnom razdoblju hrvatske književnosti". Croatica 41/61: 357-378. https://doi.org/10.17234/Croatica.41.10

Nikolić, Davor. 2019. Između zvuka i značenja. Zagreb: Disput.

Nikolić, Davor i Josipa Tomašić. 2018. "A Hidden Pot of Charm Scholarship. The History of Critical Reflections on Charms in Croatian Folkloristics". Incantatio 7/1: 177-193. https://doi.org/10.7592/ Incantatio2018_7_Nikolic_Tomashic

Oring, Elliott. 2016. Joking Asides. The Theory, Analysis, and Aesthetics of Humor. Utah: University Press of Colorado. https://doi.org/10.7330/9781607324928

Page, Ruth E. 2010. "Re-examining Narrativity. Small Stories in Status Updates". TextETalk 30/4: 423 444. https://doi.org/10.1515/text.2010.021 
Page, Ruth E. 2018. Narratives Online. Shared Stories in Social Media. New York: Cambridge University Press. https://doi.org/10.1017/9781316492390

Popović, Tanja, ur. 2010. Rečnik književnih termina. Beograd: Logos art.

Predojević, Željko. 2019. “Mudrolije. Internetski memi poslovičnoga karaktera na primjeru mrežne stranice Mudrolije sa Twittera". Etnološka tribina 49/42: 152-172. https://doi.org/10.15378/18489540.2019.42.06

Predojević, Željko. 2021a. "Humor katastrofe i internetski memi u vrijeme pandemije koronavirusa na primjeru dva instagramska profila". Anafora. Časopis za znanost o književnosti 8/1: 1-20. https:// doi.org/10.29162/ANAFORA.v8i1.1

Predojević, Željko. 2021b. "Humorističan prikaz školskog sustava u vrijeme pandemije koronavirusa na primjeru vizualno-verbalnih internetskih žanrova". Narodna umjetnost 58/1: 107-128. https://doi. org/10.15176/vol58no106

Radulović, Lidija. 2007. "Roditeljska kletva kao nevidljivo nasilje. Diskurs antimaterinstva u tradicijskoj kulturi". Etnoantropološki problemi 2/2: 137-146. https://doi.org/10.21301/eap.v2i2.8

Sadler, Neil. "Narrative and Interpretation on Twitter. Reading Tweets by Telling Stories". New Media E Society 20/9: 3266-3282. https://doi.org/10.1177/1461444817745018

Sæbø, Øystein. 2011. "Understanding Twitter TM Use Among Parliament Representatives. A Genre Analysis". U Electronic participation. ePart 2011. Efthimios Tambouris, Ann Macintosh i Hans de Bruijn, ur. Berlin, Heidelberg: Springer, 1-12. https://doi.org/10.1007/978-3-642-23333-3_1

Shifman, Limor. 2007. "Humor in the Age of Digital Reproduction. Continuity and Change in Internet-Based Comic Texts". International Journal of Communication 1/1: 187-209.

Shifman, Limor. 2014. Memes in Digital Culture. Cambridge: The MIT Press. https://doi.org/10.7551/ mitpress/9429.001.0001

Solar, Milivoj. 2007. Književni leksikon. Zagreb: Matica hrvatska.

Tomelić Ćurlin, Marijana i Anita Runjić-Stoilova. 2010. "Sapletene kletve". Anali Zavoda za povijesne znanosti Hrvatske akademije znanosti i umjetnosti u Dubrovniku 48: 377-396.

Užarević, Josip. 2008. "Protonarativ i narativ. Poslovica i vic". Anagram. Dostupno na: http://www.hrvatskiplus.org/article.php?id=1885\&naslov=protonarativ-i-narativ-poslovica-i-vic (pristup 9. 4. 2021.).

Užarević, Josip. 2012. Književni minimalizam. Zagreb: Disput.

Vásquez, Camilla. 2019. Language, Creativity and Humour Online. London, New York: Routledge. https:// doi.org/10.4324/9781315159027

Vukelić, Deniver. 2014. “Uvod u klasifikaciju verbalne magije i verbalna magija u zapisanoj usmenoj hrvatskoj tradiciji". Studia Mythologica Slavica 17: 243-270. https://doi.org/10.3986/sms.v17i0.1504

Weitz, Eric. 2016. "Editorial. Humor and Social Media”. The European Journal of Humour Research 4/4: 1-4. https://doi.org/10.7592/EJHR2016.4.4.weitz

Yus, Francisco. 2011. Cyberpragmatics. Internet-Mediated Communication in Context. Amsterdam, Philadelphia: John Benjamins Publishing Company. https://doi.org/10.1075/pbns.213

Yus, Francisco. 2021a. "Pragmatics, Humour and the Internet". Internet Pragmatics 4/1: 1-11. https://doi. org/10.1075/ip.00067.yus

Yus, Francisco. 2021b. "Incongruity-resolution Humorous Strategies in Image Macro Memes". Internet Pragmatics 4/1: 131-149. https://doi.org/10.1075/ip.00058.yus

Zappavigna, Michele. 2014. "Coffeetweets. Bonding Around the Bean on Twitter". U The Language of Social Media. Communication and Community on the Internet. Philip Seargeant i Caroline Tagg, ur. London: Palgrave, 139-160. https://doi.org/10.1057/9781137029317_7 
Zappavigna, Michele. 2017. "Twitter". U Pragmatics of Social Media. Christian Hoffmann i Wolfram Bublitz, ur. Berlin, Boston: De Gruyter, 201-224. https://doi.org/10.1515/9783110431070-008

Živković, Dragiša, ur. 1985. Rečnik književnih termina. Beograd: Nolit.

\section{ON THE LUDIC CURSE IN THE HUMOROUS DISCOURSE OF INTERNET GENRES}

The paper discusses the ironic use of the genre of the curse in the humorous discourse of internet genres. In the collective memory, the genre of the curse is a verbal magic genre that implies uttering evil words inflicting harm on someone, and in the humorous discourse of internet genres, curses are applied to some unexpected experience, thus creating an ironic opposition to what the genre of the curse assumes and its role in weblore. In addition to ironizing the genre of the curse, its atypical role of creating a humorous effect in the discourse of internet genres is also pointed out. Such humorous versions of the genre of curses in weblore are referred to as ludic curses. Ludic curses are uttered only in jest, but they retain the remnants of the belief in the power of words manifested by immanent formulations of curses, and above all the phrase dabogada (May God), which evokes the desire to harm someone, but they are applied in a humorous context which creates an incongruous situation and therefore a humorous effect. The research focuses on Instagram and Facebook user profiles of the webpage Mudrolije sa Twittera.

Keywords: curses, ludic curses, humor, weblore, social networks, internet genres, tweets, shared stories 